10. Андрющенко В. К. Модификация метода определения пролина для выявления засухоустойчивых форм рода Lycopersicon Tourn / В. К. Андрющенко, В. В. Саянова, А. А. Жученко и др // Известия Академии наук Молдавской ССР. - 1981. - № 4. - С. 55-60.

11. Степанченко Н. С. Количественное определение содержания белка // Физиол. растений. - 2011. - 58. - Р. $624-630$.

12. Stein $\mathrm{H}$. Elevation of free proline and proline-rich protein levels by simultaneous manipulations of proline biosynthesis and degradation in plants / H. Stein, A. Honig, G. Miller et al. // Plant Sci. - 2011. - 181. - P.140-150.

13. Battaglia M. Proline-rich cell wall proteins accumulate in growing regions and phloem tissue in response to water deficit in common bean seedlings / M. Battaglia, R. M. Solorzano, M. Hernandez et al. // Planta. - 2007. - 225. P. 1121-1133.

Сергеева Лариса, Бронникова Лариса. Пролин-опосредованные реакции табака на действие засоления. Предметом настоящей работы было сравнительное исследование реакций растений табака на действие летального засоления и роли свободного пролина в реализации солеустойчивости.

Методом клеточной селекции с использованием летальных для клеточных культур доз катионов Ва ${ }^{2+}$, получены устойчивые клеточные линии табака. Из них получены регенеранты R0, а также семенные поколения R1, R2. Клеточные линии и растения R0, R1 и R2 отличались устойчивостью к моделированному летальному солевому стрессу. Сравнивали реакции, сопряжённые с повышением уровня свободного пролина, у экспериментально полученных растений и исходных растений табака, который является типичным гликофитом. Растения R0 культивировали in vitro в течение 35 сугок в присутствии 20,0 г/л солей морской воды; растения R1, R2 тестировали в водной культуре 10 суток, добавляя 25,0 г/л этого же вещества.

Отмечали противоположные реакции растений табака в ответ на действие засоления: контрольные растения погибали, а экспериментальные варианты стабилизировали свой метаболизм, что проявлялось в сохранении синтеза белка. В то же время во всех растениях возрастало содержание свободного пролина. Однако аккумуляция данной аминокислоты в экспериментальных вариантах была следствием повышения её синтеза, тогда как пролин в контрольных растениях образовывался при деградации клеточных белковых компартментов. Таким образом, абсолютные значения содержания свободного пролина не могут быть гарантированным показателем солеустойчивости; следует оценивать динамику его изменений.

Ключевые слова: табак, клеточная селекция, катионы бария, засоление, устойчивость, пролин.

Sergeeva Larisa, Bronnikova Larisa. The Proline-mediated Reactions of Tobacco Plants, Cultivated Under Salinity. The comparative investigation of tobacco plants reactions on lethal salinity pressure and their proline status were the objects of the research.

On selective media with the addition of lethal for cell cultures doses of $\mathrm{Ba}^{2+}$ cations resistant tobacco cell lines occurred. Regenerants R0 and seed progenies R1, R2 were obtained from those lines. Cell lines, R0, R1 and R2 plants challenged the simulated lethal salt stresses. The comparative investigation of proline-mediated reactions of those variants and initial tobacco (pure glicophyte) were elaborated. R0 plants were cultivated in vitro during 35 days on cultural media with the addition of $20,0 \mathrm{~g} / \mathrm{l}$ sea water salts; R1 and R2 plants were tested in water culture with the addition of 25,0 g/l sea water salt during 10 days.

Control and experimentally obtained variants developed different reactions to salt pressure. Control plants eliminated. Experimental variants maintained their metabolism reflected in stable protein biosynthesis. At the same time the free proline levels increased in all genotypes. But in resistant variants these events resulted from amino acid biosynthesis, while in control plants proline appearance was the result of the protein compartments degradation. So data of free proline level are not adequate markers of the plant salt resistance. There is better to estimate the character of proline changes.

Key words: tobacco, cell selection, barium cations, salinity, tolerance, proline

Стаття надійшла до редколегії 29.09.2016 р.

УДК 712.253:581(477)

Анна Савоськіна

\title{
Оцінювання декоративності дендросозоекзотів штучних заповідних парків Українського Полісся
}

У статті оцінено ступінь декоративності дендросозоекзотів ex situ штучних заповідних парків Українського Полісся. Для цього використано нову комплексну методику оцінки декоративності, розроблену спеціально для дендро-

(C) Савоськіна А., 2016 
созоекзотів на основі оцінювання їхніх декоративних ознак. У результаті аналізу виявлено, що зі 105 видів дендросозоекзотів 69 (65,7 \%) видів мають високу декоративність та дуже високу - три види. Посередньою декоративністю відзначаються 23 (21,9 \%) види, низькою - 10 (10,0 \%) видів.

Ключові слова: Українське Полісся, декоративність деревних рослин, дендросозоекзоти, штучні заповідні парки.

Постановка наукової проблеми та ії значення. У садово-паркових ландшафтах рослинний світ найбільш динамічний компонент, а як основа будь-яких композицій він надзвичайно активний емоційнопсихологічний фактор. Зокрема, до декоративних якостей деревних рослин належать ознаки життєвої форми, крони, листків, квіток, текстури кірки та ін. Значний вплив на прояв цих властивостей мають екотопічні умови росту й розвитку деревних рослин, які за різкої зміни можуть негативно впливати на габітус рослин. Відповідно, на стан декоративності, іï посилення чи послаблення можуть впливати рельєф, освітлення, наявність сусідніх рослин і будівель тощо. У зв'язку з цим мета наших досліджень - оцінювання декоративності дендросозоекзотів еx situ штучних заповідних парків Українського Полісся.

Аналіз досліджень цієї проблеми. Для визначення оцінки декоративності окремих видів дерев і чагарників чи їхніх груп існує низка методик. Серед найбільш поширених - праці Г. Є. Мисника (1964), Н. В. Котелової та О. Н. Виноградової (1974), В. М. Билова (1978). Основні принципи естетичної оцінки хвойних паркових культурфітоценозів запропонували Г. О. Миронова й О. П. Чекалін (1997). Методику оцінювання декоративності рослин видів роду Rhododendron L. розробила I. О. Сидоренко (2008). Нам відомі й інші методики (Хороших, Хороших, 1999; Калініченко, 2003; Слюсар, Кузнецов, 2008). Наявні методики мають низку переваг і недоліків.

Однак для визначення декоративності раритетних видів екзотичних деревних рослин Українського Полісся ми скористалися новою комплексною методикою, розробленою А. С. Власенко [1]. Вона є універсальною для чотирьох типів життєвих і сезонних форм деревних рослин: листяних та хвойних, листопадних і зимо-зелених. Оцінювання декоративних ознак деревних рослин, згідно 3 цією методикою, здійснюється за чотирма основними блоками: перший - це оцінка загальної декоративності рослини, яка включає період декоративності, декоративні ознаки крони (форма, щільність, фактура) й тривалість квітування та облистнення; другий - це оцінка декоративності кірки, іiі фактури й забарвлення; третій - оцінка декоративності листків або хвої за формою, розмірами, забарвленням та сезонністю його змін; четвертий оцінка декоративності генеративних органів рослини, яка грунтується на розмірах, забарвленні, рясності квіток (мегастробілів, суцвіть), а також формі, величині, забарвленні й рясності плодів або шишок у хвойних. У шкалу свідомо не включено показники зимо-, морозо-, посухо- та жаростійкості рослини. Ступінь декоративності коливається від 13 до 90 балів й поділяється на чотири групи декоративності: IV - декоративність низька, III - посередня, II - висока, I - дуже висока [1].

Виклад основного матеріалу й обгрунтування отриманих результатів дослідження. Аналіз дендросозофлори штучних заповідних парків Українського Полісся засвідчив що на їхніх територіях наявні 105 видів, які належать до 39 родів, 19 родин, 17 порядків, трьох класів (п’ять підкласів) та двох відділів. Більшість видів належить до відділу Pinophyta - 62 види $(59,0 \%$ від загальної кількості виявлених видів). До відділу Magnoliophyta, відповідно, належить 43 (41,0 \%) види. У біоморфологічній структурі переважає група дерев - 94 (89,5 \%) види. До групи чагарників належить 11 (10,5\%) видів, деревних ліан - один [9; 10].

У результаті застосованої комплексної методики оцінки декоративності заповідних дендросозоекзотів ex situ Українського Полісся виявлено, що до IV групи належить 10 видів, III - 23, II - 69, I - три види. Для прикладу ми обрали по 10 видів дендросозоекзотів Українського Полісся з обох відділів (табл. 1).

Серед виявлених 62 представників відділу Pinophyta посередню декоративність мають 10 видів, високу - 52. Посередня декоративність (41-50 балів) властива рослинам Cupressaceae (Chamaecyparis pisifera Sieb. et Zucc., Chamaecyparis lausoniana (Andr.) Parl., Chamaecyparis thyoides B. S. P., Microbiota decussata Kom., Thua occidentalis L., Juniperus pseudosabina F. et M., Juniperus rigida Sieb. et Zucc., Platycladus orientalis (L.) Franco.), Pinaceae (Pinus banksiana Lamb., Tsuga canadensis (L.) Carr. та ін.). Хоча рослини цієї групи є вічнозеленими, однак їх декоративність посередня через невиразну форму крони, часто викривлений стовбур, дрібну хвою, дрібні плоди тощо [2; 5; 6]. Водночас вони все ж можуть бути використані у створенні фітоценокомпозицій за участю дендросозоекзотів. 
Оцінка декоративності видів заповідних дендросозоекзотів Українського Полісся

\begin{tabular}{|c|c|c|c|c|c|c|c|c|c|c|c|c|c|c|c|c|c|c|c|c|c|}
\hline \multirow{3}{*}{ 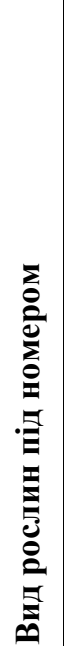 } & \multicolumn{6}{|c|}{$\begin{array}{c}\text { Загальна декоративність } \\
\text { рослини }\end{array}$} & \multicolumn{2}{|c|}{$\begin{array}{c}\text { Оцінка } \\
\text { декора- } \\
\text { тивності } \\
\text { кірки }\end{array}$} & \multicolumn{4}{|c|}{$\begin{array}{c}\text { Оцінка } \\
\text { декоративності } \\
\text { листків } \\
\text { або хвої }\end{array}$} & \multicolumn{7}{|c|}{$\begin{array}{l}\text { Оцінка декоративності } \\
\text { генеративних органів }\end{array}$} & \multirow{3}{*}{\multicolumn{2}{|c|}{ 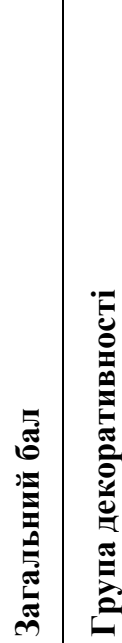 }} \\
\hline & \multirow{2}{*}{ 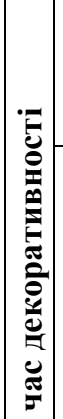 } & \multicolumn{3}{|c|}{ крона } & \multicolumn{2}{|c|}{$\begin{array}{l}\text { трива- } \\
\text { лість }\end{array}$} & \multirow[b]{2}{*}{ 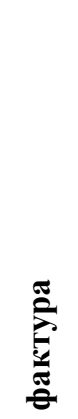 } & \multirow[b]{2}{*}{ 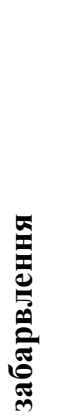 } & \multirow[b]{2}{*}{ : } & \multirow[b]{2}{*}{ 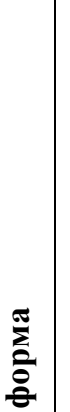 } & \multirow[b]{2}{*}{ 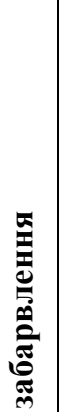 } & \multirow{2}{*}{ 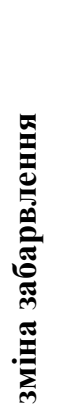 } & \multicolumn{3}{|c|}{$\begin{array}{c}\text { квітки } \\
\text { (мегастробіли) } \\
\text { суцвіття }\end{array}$} & \multicolumn{4}{|c|}{$\begin{array}{l}\text { плоди } \\
\text { (шишки) }\end{array}$} & & \\
\hline & & قे & 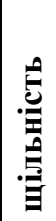 & 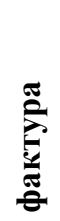 & 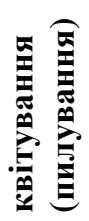 & 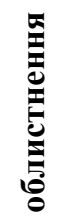 & & & & & & & 言 & 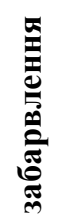 & 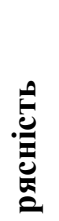 & 离 & : & 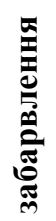 & 苞 & & \\
\hline 1 & 3 & 3 & 5 & 3 & 3 & 5 & 3 & 3 & 3 & 1 & 3 & 5 & 1 & 5 & 5 & 5 & 3 & 5 & 5 & 69 & I \\
\hline 2 & 3 & 5 & 5 & 5 & 5 & 5 & 5 & 3 & 3 & 1 & 1 & 5 & 3 & 5 & 5 & 1 & 3 & 0 & 5 & 68 & I \\
\hline 3 & 3 & 5 & 5 & 3 & 1 & 3 & 5 & 3 & 3 & 3 & 3 & 5 & 1 & 1 & 3 & 5 & 3 & 5 & 3 & 63 & II \\
\hline 4 & 5 & 5 & 5 & 3 & 1 & 5 & 5 & 3 & 3 & 3 & 3 & 5 & 1 & 5 & 1 & 5 & 3 & 1 & 1 & 63 & II \\
\hline 5 & 3 & 5 & 3 & 3 & 1 & 3 & 5 & 5 & 3 & 5 & 5 & 5 & 1 & 1 & 1 & 5 & 3 & 1 & 1 & 59 & II \\
\hline 6 & 5 & 5 & 5 & 3 & 1 & 5 & 3 & 3 & 3 & 3 & 3 & 1 & 3 & 3 & 1 & 3 & 3 & 5 & 1 & 59 & II \\
\hline 7 & 3 & 5 & 3 & 3 & 3 & 1 & 5 & 3 & 3 & 5 & 1 & 5 & 5 & 5 & 3 & 3 & 1 & 1 & 1 & 59 & II \\
\hline 8 & 5 & 5 & 5 & 1 & 1 & 5 & 5 & 3 & 3 & 3 & 3 & 1 & 1 & 3 & 1 & 5 & 3 & 3 & 1 & 57 & II \\
\hline 9 & 3 & 3 & 5 & 5 & 3 & 5 & 5 & 5 & 3 & 3 & 3 & 3 & 1 & 1 & 1 & 3 & 3 & 1 & 1 & 57 & II \\
\hline 10 & 1 & 5 & 3 & 3 & 5 & 1 & 5 & 3 & 5 & 3 & 3 & 3 & 5 & 5 & 1 & 1 & 3 & 1 & 1 & 57 & II \\
\hline 11 & 3 & 5 & 5 & 5 & 3 & 1 & 5 & 3 & 3 & 3 & 1 & 3 & 1 & 1 & 3 & 5 & 3 & 3 & 1 & 57 & II \\
\hline 12 & 3 & 5 & 3 & 3 & 3 & 1 & 5 & 3 & 3 & 3 & 1 & 3 & 3 & 5 & 1 & 5 & 3 & 3 & 0 & 56 & II \\
\hline 13 & 5 & 1 & 5 & 3 & 1 & 5 & 3 & 5 & 3 & 3 & 5 & 1 & 1 & 1 & 0 & 5 & 1 & 5 & 1 & 54 & II \\
\hline 14 & 5 & 3 & 5 & 3 & 1 & 5 & 3 & 3 & 5 & 1 & 5 & 1 & 1 & 3 & 1 & 3 & 1 & 3 & 1 & 53 & II \\
\hline 15 & 3 & 5 & 3 & 3 & 3 & 5 & 5 & 5 & 3 & 1 & 1 & 3 & 3 & 5 & 3 & 0 & 1 & 0 & 1 & 53 & II \\
\hline 16 & 1 & 3 & 5 & 3 & 3 & 5 & 3 & 3 & 3 & 1 & 3 & 3 & 3 & 5 & 5 & 1 & 1 & 1 & 1 & 53 & II \\
\hline 17 & 5 & 5 & 3 & 3 & 1 & 5 & 3 & 3 & 3 & 3 & 5 & 1 & 1 & 3 & 1 & 5 & 1 & 1 & 1 & 53 & II \\
\hline 18 & 1 & 3 & 3 & 1 & 1 & 1 & 3 & 3 & 3 & 1 & 1 & 3 & 3 & 5 & 5 & 5 & 3 & 5 & 3 & 52 & II \\
\hline 19 & 3 & 5 & 1 & 1 & 1 & 3 & 5 & 3 & 3 & 3 & 5 & 5 & 1 & 3 & 1 & 5 & 1 & 1 & 1 & 51 & II \\
\hline 20 & 5 & 5 & 3 & 1 & 1 & 5 & 3 & 3 & 3 & 3 & 3 & 1 & 1 & 1 & 1 & 5 & 1 & 3 & 1 & 49 & III \\
\hline
\end{tabular}

Примітка. 1 - Malus niedzwetzkyana Dieck ex Koehne; 2 - Cercis canadensis L.; 3 - Ginkgo biloba L.; 4 - Pseudotsuga menziesii (Mird.) Franco; 5 - Metasequoia glyptostroboides Hu et Cheng; 6 - Picea asperata Mast.; 7 - Aesculus hippocastanum L.; 8 - Abies fraseri (Purch.) Poir.; 9 - Platanus orientalis L.; 10 - Magnolia kobus DC.; 11 - Corylus colurna L.; 12 - Liriodendron tulipifera L.; 13 - Taxus cuspidata Siebold \& Zucc.; 14 - Juniperus horizontalis Moench.; 15 - Sibiraea altaiensis Schneider; 16 - Forsythia europaea Degen et Bald.; 17 - Pinus banksiana Lamb; 18 - Armeniaca vulgaris Mill.; 19 - Larix kaempferi (Lamb.) Carrière; 20 - Tsuga canadensis (L.) Carrière.

Високу декоративність (51-64 бали) має більшість видів Pinaceae (Pinus uncinata Ramond ex DC, Pinus rigida Mill, Pinus sibirica (Rupr.) Mayr., Picea jezoensis (Sieb. et Zucc.) Carr., Picea pungens Engelm., Picea glauca (Moench.) Voss., Picea asperata Mast., Abies balsamea (L.) Mill., Abies nephrolepis (Trautv.) Maxim., 
Pseudotsuga menziesii (Mird.) Franco, Larix gmelini (Rupr.) Rupr., Larix decidua Mill., Larix kaempferi (Lambert) Carr., Larix sibirica Ledeb. та інші), Taxaceae (Taxus cuspidata Sieb. et Zucc), Cupressaceae (Juniperus virginiana L., Juniperus chinensis L., Juniperus horizontalis Moench). 3 основних декоративних ознак, властивих для видів цієї групи, виділяється чітко окреслена форма крони, часто низько опущена (рід Рісеа), висока охвоєність, розміри та забарвлення хвої (рід Pinus), яскраві мега- й мікростробіли тощо. Не можна не відзначити тих представників роду Larix, які, хоча іє декоративними протягом вегетаційного сезону, однак вони незамінні для формування мальовничих паркових пейзажів. До основних декоративних ознак, характерних для цієї родини, належать ажурна легка крона, забарвлення хвої (світло-зелена навесні й жовта восени), наявність численних дрібних шишок на пагонах тощо. Ще один яскравий представник дендросозоекзотів ex situ Українського Полісся - це Ginkgo biloba L., який, крім наукової цінності (релікт й ендем), вирізняється 3-поміж інших видів ажурною кроною та жовтим забарвленням листків восени [2; 5; 6].

Рослини відділу Magnoliophyta через свої біологічні особливості є декоративними лише протягом вегетаційного сезону й окремих його періодів. Також загальна декоративність рослин цього відділу характеризується дрібними листками (Betulaceae), невиразними суцвіттями й плодами (Betulaceae, Juglandaceae, Fagaceae). Саме тому з виявлених 43 низьку декоративність мають 10 видів, посередню - 13, а високу 17, дуже високу - три.

Низькою декоративністю відзначаються 10 видів роду Betula. Однак потрібно зазначити, що представники цієї групи є незамінними деревними видами під час створення світлих або ж, навпаки, контрастних (разом із вічнозеленими видами) паркових фітоценокомпозицій.

Посередньою декоративністю характеризуються рослини Betulaceae (Alnus cordata (Loisel.) Desf., Alnus rubra Bong., Carpinus cordata Blume), Juglandaceae (Juglans regia L., Pterocarya pterocarpa (Michx.) Kunth), Fagaceae (Quercus palustris Muench., Quercus rubra L., Quercus dentata Thunb.), Eucommiaceae (Eucommia ulmoides Oliv.), Fabaceae (Amorpha californica Nutt. ex Torr. \& A.Gray, Robinia pseudoacacia L.), хоча більшість дендросозоекзотів цієї групи має чітко окреслену форму крони, середні й великі листки, які змінюють забарвлення, виразні суцвіття. Незважаючи на те, що ці рослини пізно розпускаються та рано обпадають, усе ж таки вони декоративні протягом вегетаційного сезону або окремих періодів вегетації $[3 ; 4 ; 5 ; 6]$.

До родин із високою декоративністю належать Rosaceae (Armeniaca vulgaris Mill., Sibiraea altaensis (Laxm.) Schneid., Malus sieversii (Ledeb.) M. Roem.), Araliaceae (Aralia chinensis Rehd.), Cercidiphyllaceae (Cercidiphyllum japonicum Sieb. et Zucc.), Betulaceae (Corylus colurna L.), Magnoliaceae (Magnolia kobus DC., Liriodendron tulipifera L.), Platanaceae (Platanus orientalis L.), Oleaceae (Forsythia europaea Degen et Bald.), Sapindaceae (Aesculus hippocastanum L.). Із-поміж інших видів потрібно звернуги увагу на Liriodendron tulipifera L., який відзначається не лише декоративністю квіток, а й оригінальною формою листків, що надає ажурності кронам, та його золотавим кольором восени. Гарними суцвіттями з тривалим терміном квітування характеризуються Aesculus hippocastanum L. i Magnolia kobus DC $[3 ; 4 ; 5 ; 6 ; 7 ; 8]$.

До видів, які мають дуже високу декоративність, належать представник родини Rosaceae - Malus niedzwetzkyana Dieck. Через характерне забарвлення листків, рясне квітування та декоративність плодів він $\epsilon$ незамінним видом для створення фітоценокомпозицій із дендросозофітів. До декоративних ознак, що виокремлюються 3-поміж інших деревних рослин Caesalpiniaceae (Cercis canadensis L. та Cercis chinensis Bunge), належать рожево-лілові та рожево-пурпурові квітки, яскраво-жовте забарвлення листків восени, що триває близько місяця $[3 ; 4 ; 5 ; 6]$.

Висновки та перспективи подальшого дослідження. Отже, у результаті проведеного аналізу декоративності дендросозоекзотів ex situ штучних заповідних парків Українського Полісся виявлено, що зі 105 видів більшість, а саме $69(65,7 \%)$ видів мають високу декоративність, а дуже високу - три види. Посередньою декоративністю відзначається 23 (21,9\%) види, низькою - 10 (10,0 \%).

Потрібно зазначити, що хоча більшість дендросозоекзотів ex situ є досить декоративними, але на території штучних заповідних парків Українського Полісся трапляються поодиноко, часто у вигляді солітерів, і не можуть проявити свої декоративні ознаки й, відповідно, повністю впливати на загальну декоративність паркових композицій. Тому доцільно створювати фітоценокомпозиції з участю дендросозоекзотів, які, крім декоративної, мають ще й наукову цінність.

\section{Джерела та література}

1. Власенко А. С. Оцінка декоративності дендросозоекзотів ex situ Степу України / А. С. Власенко // Науковий вісник Східноєвропейського національного університету імені Лесі Українки : наук. журн. - Луцьк : Біологічні науки, 2016. - № 7 (302). - С. 27-35. 
2. Дендрофлора України. Дикорослі та культивовані дерева й кущі. Голонасінні : довідник / М. А. Кохно, В. І. Гордієнко, Г. С. Захаренко та ін. ; за ред. М. А. Кохна, С. І. Кузнецова ; НАН України, Нац. бот. сад ім. М. М. Гришка. К. : Вища шк., 2001. - 207 с.

3. Дендрофлора України. Дикорослі та культивовані дерева й кущі. Покритонасінні. - Ч. І. : довідник / М. А. Кохно, Л. І. Пархоменко, А. У. Зарубенко та ін.; за ред. М. А. Кохна. - К. : Фітосоціоцентр, 2002. - 448 с.

4. Дендрофлора України. Дикорослі та культивовані дерева й кущі. Покритонасінні. - Ч II : довідник / [М. А. Кохно, Н. М. Трофименко, Л. І. Пархоменко та ін. ; за ред. М. А. Кохна та Н. М. Трохименко]. - К. : Фітосоціоцентр, 2005. - $716 \mathrm{c}$.

5. Калініченко О. А. Декоративна дендрологія : навч. посіб. / О. А. Калініченко. - К. : Вища шк., 2003. - 200 с.

6. Колесников А. И. Декоративная дендрология / А. И. Колесников. - М. : Лесн. пром., 1974. - 704 с.

7. Мисник Г. Е. Календарь цветения деревьев и кустарников / Г. Е. Мисник. - М. : Изд-во Мин. коммунального хоз. РСФСР, 1956 - 174 c.

8. Мисник Г. Е. До оцінки декоративності дерев та чагарників у фазах їх цвітіння та плодоношення / Г. Е. Мисник // Біологія і культура деревних та чагарникових рослин. - К. : Наук. думка, 1964. - С. 100-101.

9. Савоськіна А. М. Біоморфологічна та екологічна структура екзотичної дендросозофлори штучних заповідних парків Українського Полісся / А. М. Савоськіна // Науковий вісник Східноєвропейського національного університету імені Лесі Українки : наук. журн. - Луцьк : Біологічні науки, 2016. - № 7 (302). - С. $59-65$.

10. Савоськіна А. М. Особливості складу дендросозофітів парків-пам'яток садово-паркового мистецтва Українського Полісся / А. М. Савоськіна // Біоресурси лісових та урбанізованих екосистем: відтворення, збереження і раціональне використання : тези доп. уч. Міжнар. наук.-прак. конф. (23-24 квіт. 2015 р.). - К. : «ЦП «Компринт», 2015. - С. 166-167.

Савоскина Анна. Оценка декоративности дендросозоэкзотов искусственных заповедных парков Украинского Полесья. В статье оценена степень декоративности дендросозоэкзотов ех situ искусственных заповедных парков Украинского Полесья. Для этого использовали новую комплексную методику оценки декоративности, которая разработана специально для дендросозоэкзотов на основе оценки их декоративных признаков. В результате анализа выявлено, что из 105 видов дендросозоэкзотов 69 (65,7 \%) видов имеют высокую декоративность и очень высокую - три вида. Посредственной декоративностью отличаются 23 (21,9 \%) вида, низкой - 10 (10,0 \%) видов.

Ключевые слова: Украинское Полесье, декоративность древесных растений, дендросозоэкзоты, искусственные заповедные парки.

Savoskina Anna. Evaluation of Decorativeness of Dendrosozoekzots of the Ukrainian Polissya. In this article assessed the degree of decorativeness artificial dendrosozoekzots ex situ artificial protected parks in Ukrainian Polissya. For this purpose use a new comprehensive methodology for assessing decorativeness that is designed specifically for dendrosozoekzots based on their assessment of decorative signs. The analysis found that of the 105 species dendrosozoekzots $69(65,7 \%)$ species are highly decorativeness and very high decorativeness - the three species. Middling decorativeness are $23(21,9 \%)$ species, low decorativeness - $10(10,0 \%)$ species.

Key words: Ukrainian Polissya, decorativeness arboreal plants, dendrosozoekzots, artificial protected parks.

Стаття надійшла до редколегї 19.09.2016 р.

УДК:58.009

Дмитро Ганаба

\section{Озеленення міста Хмельницького в другій половині ХХ ст.}

У статті розглянуто особливості озеленення міської інфраструктури Хмельницького в другій половині ХХ ст. На основі документів відділу міського комунального господарства проаналізовано стан озеленення міста. Указано на масштабність комплексу заходів з озеленення, що здійснювалися на основі партійних і державних програм. Позитивний фактор у процесі озеленення - залучення громадськості у висадці та догляді за молодими насадженнями. Характерним недоліком у процесі озеленення, що набуває поглиблення й дотепер, є безсистемність у доборі асортименту рослин, незначна різноманітність їх видового складу, відсутність наукового підходу в проектах озеленення міста тощо. У процесі озеленення практично не враховували кліматичних характеристик міської території, санітарно-гігієнічних умов й екологічних особливостей урбанізованого середовища тощо.

Ключові слова: деревні насадження, озеленення, урбоекологічна система, комплекс заходів, методи, рослини.

(ㄷ Ганаба Д., 2016 